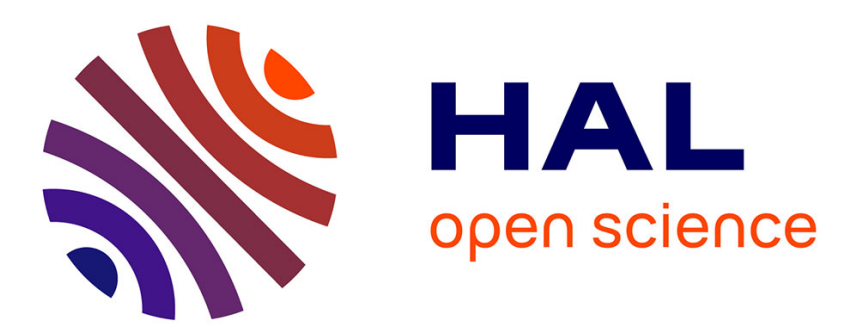

\title{
Design performance and possible applications of high efficiency thin film polycristalline CdS solar cells
}

\author{
Fred A. Shirland
}

\section{To cite this version:}

Fred A. Shirland. Design performance and possible applications of high efficiency thin film polycristalline CdS solar cells. Revue de Physique Appliquée, 1966, 1 (3), pp.178-178. 10.1051/rphysap:0196600103017801 . jpa-00242711

\section{HAL Id: jpa-00242711 \\ https://hal.science/jpa-00242711}

Submitted on 1 Jan 1966

HAL is a multi-disciplinary open access archive for the deposit and dissemination of scientific research documents, whether they are published or not. The documents may come from teaching and research institutions in France or abroad, or from public or private research centers.
L'archive ouverte pluridisciplinaire $\mathbf{H A L}$, est destinée au dépôt et à la diffusion de documents scientifiques de niveau recherche, publiés ou non, émanant des établissements d'enseignement et de recherche français ou étrangers, des laboratoires publics ou privés. 
DESIGN PERFORMANCE AND POSSIBLE APPLICATIONS OF HIGH EFFICIENCY THIN FILM POLYCRISTALLINE CdS SOLAR CELLS ( ${ }^{1}$ )

\author{
Fred A. SHIRLAND
}

Electronic Research Division, Clevite Corporation, Cleveland, Ohio, U. S. A.

Résumé. - On retrace l'histoire des cellules solaires à couches minces de CdS, depuis leur première mise en pratique en 1955, jusqu'à maintenant. On décrit les facteurs qui ont contribué à l'évolution des cellules actuelles, légères et de grande surface, à 4 à $8 \%$. On indique les différents procédés de fabrication de ces cellules avec leurs avantages et leurs inconvénients. On jette un bref coup d'œil sur les étapes de la fabrication des systèmes actuels de cellules à haut rendement, ainsi que sur les paramètres les plus importants. On présente en détail les caractéristiques de fonctionnement des meilleures cellules actuelles, ainsi que les effets de l'intensité lumineuse et de la température sur la tension, le courant et la puissance fournie la réponse spectrale et les facteurs dont dépend la stabilité de la cellule. On discute brièvement les possibilités de perfectionnement de ces cellules, et on énumère certaines de leurs applications probables dans l'espace et sur terre.

Abstract. - The history of the development of the thin film CdS solar cell is traced from its first reduction to practice in 1955 to the present. The major factors which contributed to the evolution of the present 4 to $8 \%$ large area light weight cells are described. The various possible constructions of CdS thin film solar cells are described along with advantages and disadvantages of each. A brief outline if given of the steps in fabricating the present design high efficiency cells along with the more important process parameters. The operating characteristics of the best present state-of-the-art cells are presented in detail including the effect of light intensity and temperature on the voltage, current, and power output, the spectral responses, and the factors affecting cell stability. There is a brief discussion of the possibilities for further improvements in these cells, and a listing of some of their probable applications in space and on earth.

(1) Article publié dans Adø. Energy Cons., 1966, 6, no 4, p. 201-222. 